\title{
Continuing Professional Development of Teachers: Interplay of the School Management, School Climate, Motivation and Incentives ${ }^{1}$
}

\author{
Kristinka Ovesni ${ }^{2}$ \\ Department for Pedagogy and Andragogy, Faculty of Philosophy, \\ University of Belgrade, Serbia \\ Emina Hebib \\ Department for Pedagogy and Andragogy, Faculty of Philosophy, \\ University of Belgrade, Serbia \\ Vera Radović \\ Teacher Education Faculty, \\ University of Belgrade, Serbia
}

\begin{abstract}
This study is aimed to explore interconnections of incentives and motivation that instigate and affect teachers to participate in programs for continuing professional development of teachers (CPDT) with organizational characteristics (effective school management and supportive school climate) that support teachers' participation in the CPDT programs, and their satisfaction with these programs. The sample of teachers from 92 primary schools in Serbia $(N=1162)$ were included. The data were collected by three instruments that consisted of 93 items in total, that had to measure perception of: supportiveness of the school management, the school climate, and the different incentives and motives. The collected data were subjected to a few common (frequencies, std. deviation, means, etc.) and more complex statistical proceedings (exploratory factor analysis, confirmatory factor analysis, and structural equation model analysis). The results indicate complex interplay of motivation and incentives with perceived school management and perceived school climate, with emphasis on requirement for detailed planning, development and distribution of CPDT programs that are useful for everyday activities of teachers, for their self-realization and for improvement of their performance, while in this process special attention should be given to development of effective school management and school climate conductive for teacher's continuing professional development.
\end{abstract}

Keywords: incentives, motivation, programs for continuing professional development of teachers, school climate, school management.

1 This article is a result of the project „Models of evaluation and strategies for improvement of education quality in Serbia", No 179060 (2011-2019), financially supported by the Ministry of Education, Science and Technological Development, Republic of Serbia.

2 kovesni@f.bg.ac.rs 


\section{Introduction}

The recent studies that consider teaching as a profession have displayed the tendency to three approaches to the continuing professional development of teachers (CPDT).

A first approach is based on ideas about education as a process of fulfilment of predetermined goals, where the teachers' role is perceived as an application of the appropriate teaching procedures and techniques that would provide realization of anticipated outcomes. A second approach resulted from understanding of education as a practice in the complex social context, while the main teachers' role evolves from the process of making decisions about different interventions and actions in accordance to determinants of context, i.e. to circumstances which can modify the activity. A third approach is established on the idea that education is not only a process of individual development, but social activity, while consequently, as Carr and Kemmis (Carr \& Kemmis, 2000) claims, the role of teacher should be understood as a systematic reflection of all domains of his/ her practice. For a better understanding of a very complex teachers' role, we consider the teacher not only as an educational technician or an educational practitioner, but as a professional educational planner, strategist, manager of learning. For this purpose, we adopted interdisciplinary, holistic perspective based on complex theoretical insights from different, but intertwined fields of pedagogy and andragogy.

Considering relationship between practical competence and professional knowledge not only as influence of developed theoretical and empirical findings on practice, but also as a process of development of knowledge through reflection of own practice, CPDT could be defined as a construct derived from the complex and continuously changing practical actions and reflections about them (Carr \& Kemmis, 2000).

The constructivist approach to teaching and to teachers' roles is based on understanding of CPDT as an integral part of the teachers' job (Stančić, 2015). All possible stimuli, challenges, support, and feed-back are considered as the learning opportunities for teachers, because they open possibilities to develop knowledge and skills, to experiment with innovations, or to perform new on-the-job activities (Clement \& Vanderberghe, 2001).

From the andragogic viewpoint, CPDT as planned, continuing, systematic process based on the concept of lifelong learning is perceived as one of key components of provision and development of the quality of education (Ovesni, Hebib, \& Radović, 2016). The provision and development of the quality of education - as a general determinant of reforms, and as a recognized and declared tendency of development of European school systems in the last decades of 20th and the first decades of 21st century - is a complex, generative process of related conceptual and practical changes in education and CPDT. In the legislative acts, for the purpose to ensure and to raise up quality of education in the European school systems, wide range of activities, different possibilities and solutions for development in the field of education expanded (European Commission, 2007). Based on strategic goals of EU, these possibilities are established by: recognition of needs to increase school systems' efficacy and efficiency, direction to establish social cohesive, inclusive society, to develop democratic society focused on enhancing mobility, cooperation and integration (European Commission, 2010). 


\section{Continuing Professional Development of Teachers in Serbia - Legal Foundation}

The major changes in the domains of initial education and CPDT started in Serbia in the beginning of 21 th century as a part of complex process of reforms. As stated by law and subsidiary legislation concerning primary and secondary schools in Serbia, CPDT is mandatory. During professional development, teachers could reach appropriate levels of achievement (Zakon..., 2013).

The subsidiary legislation considers professional development as the complex process aimed to improve quality of teachers' performance, to improve pupil's development or levels of achievement. CPDT is realized as an outcome of the developmental projects in schools by internally planned and accomplished activities or externally, through participation in trainings within the accredited programs.

The process of accreditation of these programs involve the guidelines and principles, application to the public call for submission of bid, external reviews of programs by appointed expert commissions, according to predefined priority fields of CPDT, and according to required program's standards of quality. Realization of this process is provided by professional body - Institute for Improvement of Education (Zavod za unapređivanje obrazovanja i vaspitanja).

Planning of CPDT is based on external evaluation of school performance and on school's self-evaluation, plans of CPDT are an integral part of programs developed by school, while teachers have a legal responsibility to follow up the personal carrier development and to reflect it.

Based on these regulations (Pravilnik o stalnom stručnom usavršavanju i sticanju zvanja nastavnika, vaspitača i stručnih saradnika, 2015), the plans for the CPDT programs in Serbia are formed upon different, intertwined needs: social needs (determined by the Ministry of Education, Science and Technological Development RS), school needs (determined by school management), and individual educational needs of teachers (expressed in the personal carrier development plans, portfolios).

\section{Conceptual Framework: Continuing Professional Development of Teachers and the School Characteristics}

The quality of individual and the managerial team's performance are important supportive requirements for teachers' professional engagement and development. The concepts of noncoercive and effective educational management explains provision of the context for successful school performance and for development of employees. Development of organizational climate supportive to learning is necessary for modeling school as learning organization or learning community (Radulović, 2016), while school management, which designs and facilitate organizational context and climate supportive to teachers' development have the main responsibility for this transformation. Therefore, this study is grounded in pedagogy and andragogy, in self-determination theory (SDT), and in the concepts of: noncoercive and effective educational management, organizational climate and learning organization to generate insights into the relationships between the 
CPDT, supportiveness of school climate and school management, and different internal incentives (motivators) for participation in the CPDT (monetary rewards, certification, usefulness, helpfulness in everyday activities, satisfaction of educational needs, possibility for self-realization and satisfaction with CPDT programs).

Effective School Management. Improvement of the school practice (advancement of the conditions for educational process and of the educational process) besides the improvement of the school effectivity (advancement of quality of the outcomes of school practice) is the essential component of the process of development of the quality of school education (Bollough, et al, 1997, Sparks, 1995, as cited in Smith, Hofer, Gillespie, Solomon, \& Rowe, 2003; Harris \& Chrispeels, 2006). The ways and the effects of support given to teachers in conceptualization and realization of the school activities by school management and leadership determine quality of the processes of teaching and learning, affecting this way quality of the school and pupil's outcomes (Caldwell, 2003).

In the descriptions and explanations of the term "effective school management" - participative, non-directive, integrative, distributive, transformative, instructive, etc. are common attributes of the school leadership and management (Hausman \& Murphy, 2015). The main characteristics of the school leadership and management described with those attributes are:

- leading role compelled by professionalism and by creativity instead the formal position in the institution; goal-orientation in school work; overall participation of all school actors in educational consultations, discussions and negotiations in the processes of making all kind of decisions in the school (Moos \& Huber, 2007);

- orientation to actions aligned with individual and institutional needs and with the characteristics of the context aimed to improvement of school practice; orientation to continuing learning and to the development of pupil's capacities and to the development of all employees (Bennett, 2003);

- efficient communication with school staff and with school context aimed to creation of joint vision of the school development (Mooney \& Mausbach, 2008).

The discourses about main characteristics of the effective school management are based on: the concepts of school as an institution characterized by the cooperation and team work, the mentorship and instructional work, the evaluative activities and action researches, the openness toward context and toward development of the local partnership. Some authors consider that they are result of shifting focus in observation of the essential characteristics of school as an institution - from a hierarchical to a community and learning-centered organization (Hausman, \& Murphy, 2015) or toward to school as a cooperative learning community (Carr, Herman, \& Harris, 2005).

Running school as a professional learning community (i.e. school as supportive context for successful realization of professional teacher's roles, and for teacher's professional development) is related to strategic management focused to the development of teaching and learning practice in school (Mooney, \& Mausbach, 2008; Stoll, Bolam, McMahon, Wallace, \&Thomas, 2006), and to all activities and processes related to provision of efficient functioning and development of institution (Gamage, 2009). School management can be effective "only if school is strategically-oriented, learning organization, and if they are em- 
phasizing the importance of continuing professional development of teachers" (Ovesni et al., 2016, p. 149). Therefore, it is very important for school management and leadership to have developed reward systems, and mechanisms for making decision about continuing and systematic improvement of competencies of school staff. The following hypothesis summarizes our discussion:

Hypothesis 1: Perception of the school management as effective has a positive effect on participation in CPDT programs and satisfaction with them.

School Climate. The importance of school climate for the quality of education have been recognized by scholars over century ago and have been of systematical research interest since 1950s. In the last few decades school climate was included as an issue in the formal school documents aimed to implement certain political solution in the field of education and underlined as important topic in discourses in the field of education. As Thapa and associates (Thapa, Cohen, Guffey, \& Higgins-D'Alessandro, 2013) suggests based on performed review of the pedagogical literature, the explanations of the meaning and content pointed out that the concept of school climate is inherently multidimensional and difficult to define, while it's improvement dispose on dialogue and collaboration of pupils, teachers, and other school staff. A descriptive definition of this multidimensional construct point out interconnectedness of school climate with: the characteristics of school as a physical and social context for the processes of teaching and learning, the characteristics of teaching program and teaching process, the characteristics of relationship between pupils, teachers, other staff, managers, and school associates, the characteristics of communication between school staff, relations between all participants in the process of education in the school, and relations between school and all people in the community relevant for the process of education (especially parents), engagement through relationship building and active membership in the learning community, extent to which the school is perceived as a safe and caring place for pupils and for school staff, etc. (Adelman \& Taylor, 2005; Cohen, 2006; Hebib, 2013; Hebib, \& Žunić Pavlović, 2018; Grossman, Wineburg, \& Woolworth, 2000 as cited in Smith et al., 2003).

The research findings about school climate as important factor of the school performance and as a predisposition for change allows raising questions about effects of school climate on educational management (Osborne \& Brown, 2005), accomplishment of the strategies of school development (Gruenert \& Whitaker, 2015), development of school as stimulative context for learning and development of pupils, high performance, and CPDT (Caldwell, 2003). Based on mentioned literature, this research hypothesis is proposed:

Hypothesis 2: Perception of the school climate as supportive has a positive effect on teachers' professional development.

Motivation and Incentives That Instigate and Affect Teachers to Participate in CPDT Programs. Motives and the experiences of external and internal forces that instigate and affect teachers to participate in CPDT programs has only rarely been studied. Although Ryan and Deci (2017) distinguished many different forms of motivation (extrinsic, i.e. external, introjected, identified, integrated, and intrinsic forms of motivation) and 
amotivation, which can be present in job performance, and emphasized that "people are not only more or less motivated, as most motivation theories have suggested, but they can be motivated by intrinsic and by varied types of extrinsic motivations, often simultaneously" (Ryan \& Deci, 2017, p. 16) - most explanations of teachers' motivation to participate in CPDT programs are established on extrinsic and intrinsic forms of motivation. Such "reasoning evolved out of the view of intrinsic motivation as a growth-oriented source of energy that leads people to take on optimal challenges in an attempt to master their environments by stretching their skills and knowledge, whereas extrinsic incentives prompt motivation that is more involved with the exercise of existing skills and knowledge and with a more focused and rigid pursuit of a goal extraneous to the learning itself" (Ryan \& Deci, 2017, p. 174).

Mayr \& Müller (2010) indicate that motivation of teachers for CPDT is a key to the quality development of teaching, which can make a decisive contribution to the maintaining and developing their professional skills. Motivation of teachers to participate in CPDT programs is an individual factor of teachers' development, which should be based on the individual plan, built on the self-evaluation of their own needs, and an organizational factor, related to the school management and school climate. Because the motivation is psychological construct, that "cannot be observed or measured directly" (Minton, 2013, p. 613), researchers usually opt to the common use of indirect measures.

Some authors (Livneh \& Livneh, 1999, as cited in Smith, Hofer, Gillespie, Solomon, \& Rowe, 2003; Šefer, 2015) consider that three factors predict participation of teachers in CPDT: high internal motivation to learn (built on educational needs, self-realization), high external motivation to learn (certification, career mobility), and lower levels of formal education. As main motives for participation of teachers in CPDT programs Smith and others (Smith et al., 2003) specified career mobility and gaining new skills/knowledge, while as most important incentives they indicated salary enhancement and certificate maintenance. In addition, as Sinclair and others (Sinclair, Dowson, \& Mclnerney, 2006) suggest, motives and incentives for participation in CPDT programs vary with age, though others (Smith et al., 2003) emphasized influence of professional autonomy, help in everyday activities, system of evaluation, employees' tenure, career mobility, etc. Furthermore, besides common incentives (privileges, rewards) emphasized self-realization, usefulness, and relatedness satisfaction as motives and incentives that positively predict the participants' intentions to continue with learning opportunities (Ryan \& Deci, 2017). Therefore, the incentives and motives that have positive effects on teachers' professional development can be regarded as the composite of several measurable variables or constructs: usefulness, help in everyday activities, rewards, certificates (as a form of privileges), satisfaction with CPDT, self-realization, educational needs. These findings led us to our last set of hypotheses:

Hypothesis 3: Different incentives and motives have positive effects on participation in CPDT programs and satisfaction with them.

Hypothesis 4: Effects of some organizational characteristics (effective school management, supportive school climate) on participation in (PDT programs and satisfaction with them are influenced by different incentives and motives. 


\section{Methods}

The goal of this empirical quantitative study was to examine motivation and incentives that drives teachers to participate in CPDT programs and to be satisfied with them, concerning some organizational characteristics (effective school management and supportive school climate). Therefore, the main objectives of this study were to determine effects (presence, positive or negative value) among the variables related to perception of the school management as effective, perception of the school climate as supportive, and different incentives and motives (usefulness of participation in CPDT programs, rewards for participation in CPDT programs, helpfulness in everyday activities after participation in CPDT programs, certificates for participation in CPDT programs, individual educational needs of teachers as incentive for participation in CPDT programs, and self-realization as incentive for participation in CPDT programs) on participation in CPDT programs and satisfaction with them.

Data Collection and Sample Characteristics. The population for this study were all teachers from Serbia, employed in primary schools. Data were collected from a simple random sample of 1162 teachers from 92 primary schools in Serbia. The paper-and-pencil questionnaires were distributed to 1200 teachers. A total of 1162 surveys were returned (response rate $=96.8 \%$ ). Participation in the study was voluntary and anonymously.

The age of the participants ranged from 25 to 65 years, with a mean age near 42.5 years. Female participants $(N=1002 ; 86.2 \%)$ highly outnumbered male participants $(N=160 ; 13.8 \%)$. Average employees' tenure (number of years worked in the school) ranged from 6 months to over 20 years, with a mean near 13 years and 9 months. Among the respondents, $0.1 \%$ had a master degree or higher, $89.8 \%$ had a four-year university degree, and $10.2 \%$ had a bachelor or college degree. All of them participate in CPDT programs (100.0\%).

Instruments. A five-point modified Likert type scale with anchors ranging from 1 ("strongly disagree") to 5 („strongly agree") was used for all measurement scales. Initially, the pull of 93 items (that composed the three initial instruments that had to measure perception of: supportiveness of the school management, the school climate, and the different incentives and motives) were developed and the factor structure were initially analyzed by exploratory principal component factor analysis using maximum likelihood extraction method, and Promax rotation method with Kaiser normalization.The 18-items instrument (Cronbach's $\alpha=0.82$ ) intended to measure perception of supportiveness of school management was developed based on indicators found in prior studies (Gamage, 2009; Mooney \& Mausbach, 2008; Ovesni et al., 2016; Stoll et al., 2006). The perception of school climate was measured with 22-items instrument (Cronbach's $\alpha=0.92$ ) developed following earlier studies (Adelman \& Taylor, 2005; Caldwell, 2003; Cohen, 2006; Gruenert \& Whitaker, 2015; Osborne \& Brown, 2005; Ovesni et al., 2016). The most complex instrument, that had to measure perception of the different incentives and motives (IMS) consisted of 53 items (Cronbach's $a=0.85$ ), and divided into seven separate sub-scales (Satisfaction with CPDT programs, Usefulness, Rewards, Help in Everyday Activities, Certificates, Educational Needs, and self-Realization sub-scales), that after performed component factor analysis corresponded to the extracted factors. The instrument was developed based 
on related items found in prior studies (Mayr \& Müller, 2010; Ryan \& Deci, 2017; Sinclair et al, 2006; Minton, 2013; Smith et al., 2003).

All three initially included instruments have high internal reliability coefficients (Cronbach's a for all of them was above .8, that means that deletion of certain items would improve reliability of instrument), while the values of corrected item-total correlation were all above .3 and below .7, that means that all items correlate very well (but not too strongly) with the scale overall. This process resulted in extraction of nine factors that we in later process of confirmatory factor analysis, and structural equation model analysis treated separately, as follows:

- School Management (MGM) scale was reduced to two items (the item with highest loading was Management in my organization is strategically focused to the development of teaching and learning practice through CPDT programs).

- School Climate (SC) scale was reduced to eleven items (the item with highest loading was My organization demands participation in a certain CPDT programs).

- Satisfaction with CPDT programs (SCPD) part of IMS scale designed to measure satisfaction with CPDT programs was reduced to four items (the item with highest loading was I am satisfied with job-related learning during participation in CPDT programs).

- Usefulness (U) part of IMS scale designed to measure perception of usefulness of participation in CPDT programs was reduced to two items (the item with highest loading was Participation in CPDT programs are useful for my job performance).

- Rewards (R) part of IMS scale, designed to measure rewards for participation in CPDT programs was reduced to two items (the item with highest loading was Participation in CPDT programs bring rewards such as privileges, status, security, etc).

- Help in Everyday Activities (H) part of IMS scale, designed to measure perception of helpfulness in everyday activities after participation in CPDT programs was reduced to three items (the item with highest loading was CPDT programs provides me with knowledge relevant to my job).

- Certificates (C) part of IMS scale, designed to measure perception of different aspects of certificates for participation in CPDT programs was reduced to two items (the item with highest loading was Participation in CPDT programs provides me with certificates that are important for my promotion).

- Educational Needs (EN) part of IMS scale, designed to measure the individual educational needs of teachers as incentive for participation in CPDT programs was reduced to four items (the item with highest loading was I would like to participate in planning and organizing CPDT programs).

- Self-Realization (SR) part of IMS scale, designed to measure self-realization as incentive for participation in CPDT programs and satisfaction with them, was reduced to four items (the item with highest loading was Participation in CPDT programs bounce my self-respect).

Respondents reported age, gender, and employees' tenure. We measured age by asking respondents to indicate one of three response options ranging from 1 (under 35) to 3 (50 
or older). Gender was measured and coded with women as 1 and men as 2. Furthermore, we measured employees' tenure by asking respondents to indicate one of seven response options ranging from 1 (less than one year) to 7 (20 years or more).

Data Analyses Techniques. The first step in data analyses was to conduct the means, standard deviations, intercorrelations, and Cronbach's alpha of all the study variables. The next step was to conduct exploratory factor analysis on reflective latent variables (Maximum likelihood, Promax rotation, Kaiser normalization, with IBM SPSS Statistics 23). For discriminant validity of the scale measures we performed a confirmatory factor analysis (CFA, with AMOS 23). To test the causal relationships between variables in the hypothesized model structural equation model analysis was conducted with AMOS 23.

\section{Results}

Assessment of Model Fit. To provide support for the discriminant validity of the scale measures we conducted a confirmatory factor analysis (CFA) that included each of the ten latent study variables to ensure all items produced the expected factor structure. All loadings were above 0.65 , convergent and discriminant. The results of $C F A$, albeit large sample, showed that goodness-of-fit statistics indicate an acceptable fit to the data (degrees of freedom $[d f]=300 ;$ chi-square $\left[X^{2}\right]=669.973 ; x^{2} /$ degrees of freedom $[d f]=2.233$; root mean square error of approximation $[R M S E A]=0.033 \leq 0.06$; root mean square residual $[R M R]=0.032 \leq 0.05$; Tucker-Lewis index $[T L I]=0.974 \geq 0.9$; comparative fit index $[C F I]$ $=0.979 \geq 0.9$; incremental fit index $[I F I]=0.980 \geq 0.9$; overall goodness of fit index $[\mathrm{GFI}]=$ $0.960 \geq 0.9$ ); Bentler-Bonett normed fit index $[N F I]=0.964 \geq 0.9$.

As it is shown in the Table 1, lower values of error-term detection supported the well-defined measurement model in terms of good fit between the measurement model and the collected responses ( $R M S E A=0.025 \leq 0.06 ; R M R=0.038 \leq 0.08$ ).

Table 1

Confirmatory Factor Analysis (CFA) - Model Fit Summary

\begin{tabular}{ccccccccccc}
\hline Model fit indices & $\mathrm{df}$ & $\mathrm{X}^{2}$ & $\mathrm{X}^{2} / \mathrm{df}$ & $\mathrm{RMSEA}$ & $\mathrm{RMR}$ & $\mathrm{GFI}$ & $\mathrm{CFI}$ & $\mathrm{NFI}$ & $\mathrm{TLI}$ & $\mathrm{IFI}$ \\
\hline $\begin{array}{c}\text { Measurement } \\
\text { model }\end{array}$ & 300 & 669.973 & 2.233 & 0.033 & 0.032 & 0.960 & 0.979 & 0.964 & 0.974 & 0.980 \\
\hline
\end{tabular}

Although high value of chi-square, a measure contingent on sample size, could suggest possible issues (as result of large sample) in support of the acceptable measurement model, calculated $X^{2} / d f$ ratio is a more appropriate measure for large samples. As suggest in Khine, value less than $3.00\left(\chi^{2} / d f=2.233\right)$ is acceptable and indicates that the model is an adequate fit to the data (Khine, 2013). Besides, all other model fit indices were found to be acceptable in terms of goodness of fit.

On the level of parameters, all path coefficients from latent constructs to their corresponding indicators were significant at $p \leq 0.000$ and their nominal values were high 
(ranging from 0.650 to 0.949 for standardized coefficients), that provide evidence for convergent validity (Hoyle, 2012).

As it is shown in the Table 2, convergent validity is evident by AVE nominal values (all above 0.5 ), while reliability is evident by nominal values of $C R$ (all above 0.7 ). Furthermore, discriminant validity is evident by nominal values of square roots of $A V E$, that being greater than any inter-factor correlation on the matrix.

Table 2

Composite reliability, Average Variance Extracted, Maximum Shared Variance, and Maximum Reliability

\begin{tabular}{|c|c|c|c|c|c|c|c|c|c|c|c|c|c|c|}
\hline & $\mathrm{CR}$ & AVE & MSV & $\operatorname{MaxR}(\mathrm{H})$ & C & CPDT & EN & SR & MGM & $\mathrm{H}$ & SCPD & $\mathrm{R}$ & $O C$ & U \\
\hline 1 & .814 & .689 & .301 & .880 & .830 & & & & & & & & & \\
\hline 2 & .862 & .511 & .133 & .933 & .101 & .715 & & & & & & & & \\
\hline 3 & .825 & .703 & .392 & .951 & .286 & & & & & & & & & \\
\hline 4 & .900 & .694 & .301 & .970 & .549 & .134 & .496 & & & & & & & \\
\hline 5 & .752 & .603 & .151 & .973 & -.128 & -.095 & -.219 & -.320 & & & & & & \\
\hline 6 & .942 & .890 & .248 & .981 & .312 & .333 & .360 & .455 & -.177 & & & & & \\
\hline 7 & .855 & .666 & .392 & .984 & .308 & .338 & .626 & .519 & -.325 & .498 & & & & \\
\hline 8 & .890 & .801 & .151 & .986 & -.134 & -.069 & -.105 & -.137 & .389 & -.151 & -.125 & & & \\
\hline 9 & .824 & .701 & .138 & .987 & .047 & -.365 & -.058 & -.037 & .371 & -.061 & -.181 & .205 & & \\
\hline 10 & .789 & .659 & .107 & .988 & .211 & .112 & .319 & .301 & -.119 & .209 & .327 & .106 & -.002 & \\
\hline
\end{tabular}

Note. 1 - Certificates; 2 - CPDT; 3 - Educational needs; 4 - Self-realization; 5 - School management; 6 - Help in everyday activities; 7 - Satisfaction with CPDT programs; 8 - Rewards; 9 - School Climate; 10 - Usefulness

As we expected, significant correlations were found among observed variables. MGM ( $r=0.104 ; p \leq 0.000384)$ and SC $(r=0.409 ; p \leq 0.00001)$ significantly correlate with participation in CPDT programs. In addition, we found significant correlations among incentives and motives that have positive effects on teachers' professional development and participation in CPDT programs: $U(r=0.098 ; p \leq 0.000823) ; R(r=0.082 ; p \leq 0.005159)$; $\operatorname{SCPD}(r=0.339 ; p \leq 0.00001) ; H(r=0.343 ; p \leq 0.00001) ; C(r=0.105 ; p \leq 0.000337) ; E N(r=0.145$; $p \leq 0.00001)$; $S R(r=0.131 ; p \leq 0.00001)$.

However, we also found significant correlations between independent variables MGM and SC ( $r=0.378 ; p \leq 0.00001)$, as well as among incentives and motives that have positive effects on teachers' professional development $(r=0.417 ; p \leq 0.00001)$. Therefore, we used the variance inflation factor (VIF) scores in regression models to check for multicollinearity. In the regression model, all factors' VIF scores were below $3.00(O C=1.166$; $M G M=1.166 ; U=1.212 ; R=1.068 ; S C P D=2.087 ; H=1.474 ; C=1.460 ; E N=1.844 ; S R=1.994)$. Results showed absence of multicollinearity, which suggest that all included variables are sufficiently linear to be tested in structural equation model.

Hypothesis Testing. By using AMOS 23 we tested our study's hypotheses. As it is shown in the Table 3, analyses of structural model (Figure 1) provide an acceptable fit to the data. The results of tests for the model showed that goodness-of-fit statistics indicate an acceptable fit to the data (chi-square $\left[X^{2}\right]=268.048 ;[X 2 / d f]=2.169 ;[R M S E A]=$ $0.041 \leq 0.06 ;[T L I]=0.973 \geq 0.9 ;[C F I]=0.992 \geq 0.9 ;[I F I]=0.992 \geq 0.9 ;[N F I]=0.992 \geq 0.9)$. 
Table 3

SEM -- Model Fit Summary

\begin{tabular}{lccccccc}
\hline & $X^{2}$ & $X^{2} / d f$ & RMSEA & CFI & NFI & TLI & IFI \\
\hline $\begin{array}{l}\text { structural } \\
\text { model }\end{array}$ & 268.048 & 2.169 & 0.041 & 0.992 & 0.992 & 0.973 & 0.992 \\
\hline
\end{tabular}

As it is shown in the Table 4, results of the Test of Mediations using Bootstrapping indicate that Hypothesis 1 can be supported, i.e. that perception of the school management as (not) effective have significant direct effects on SCPD ( $\beta=-0.096)$ and CPDT $(\beta=0.120)$. The results also showed that the path coefficient between SC and SCPD $(\beta=-0.082)$, and SC and CPDT ( $\beta=-0.385)$, was statistically significant. Therefore, Hypothesis 2 was supported.

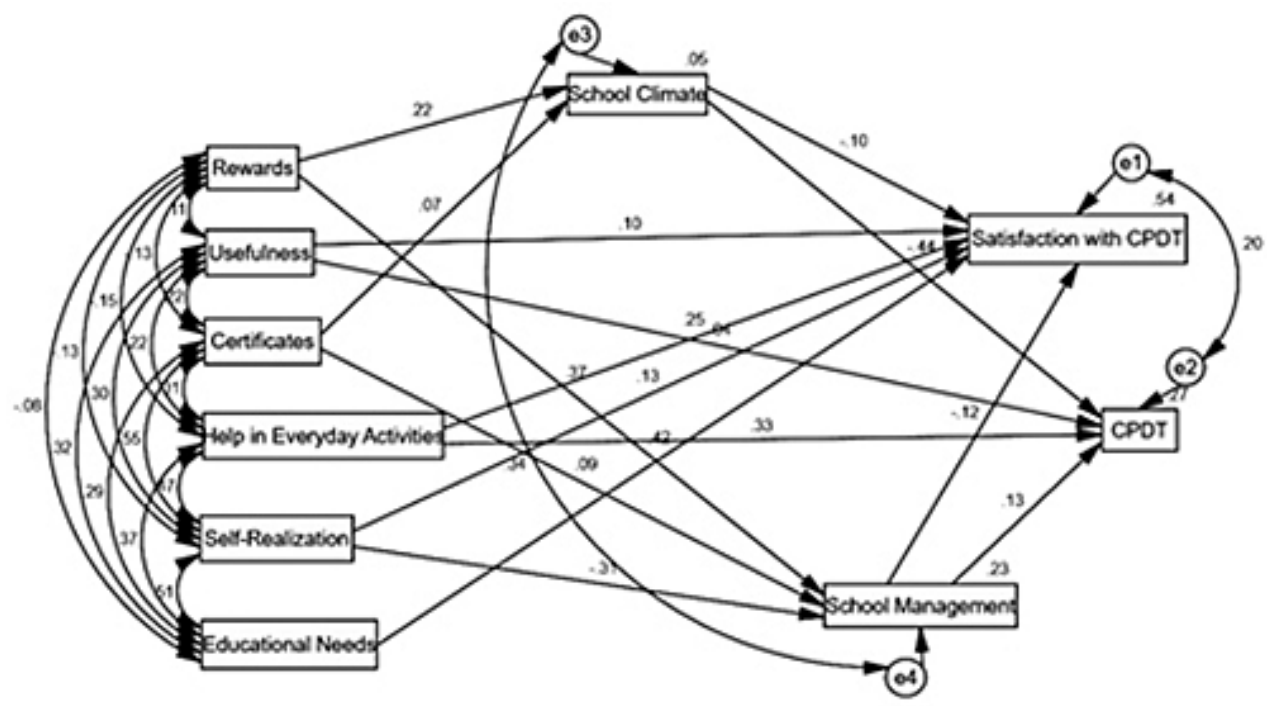

Figure 1. A Structural Equation Model with Standardized Estimates

Note. $\mathrm{N}=1162$; control variables were omitted for simplicity.

Five of six included measured incentives showed statistically significant direct effects on SCPD and CPDT: for usefulness and SCPD path coefficients were $(\beta=0.090)$, for help in everyday activities and SCPD were $(\beta=0.228)$, and for fulfilment of teacher's educational needs and SCPD were $(\beta=0.373)$. Thus, Hypothesis 3 , that different incentives and motives have positive effects on participation in teachers' professional development programs was almost fully supported for all included incentives.

Besides, as it is shown in the Table 4, self-realization showed statistically significant direct effects with mediator (effective school management) $[\beta=0.122]$, and statistically significant indirect effects $[\beta=0.034]$ on SCPD. Rewards and possibility to obtain certificate showed very interesting, similar interplay. Both as incentives showed statistically signifi- 
cant indirect effects on SCPD through supportive school climate as mediator, respectively for rewards and certificates $(\beta=-0.015 ; \beta=-0.007)$, i.e. through effective school management as mediator $(\beta=-0.028 ; \beta=-0.010)$; same incentives showed statistically significant indirect effects on CPDT through supportive school climate as mediator $(\beta=-0.071$; $\beta=-0.034)$, and, through effective school management as mediator $(\beta=0.035 ; \beta=0.012)$. Finally, self-realization showed statistically significant indirect effects $[\beta=-0.043]$ on CPDT through effective school management as mediator. Thus, Hypothesis 4 was supported.

Table 4

Results of the Test of Mediations using Bootstrapping

\begin{tabular}{|c|c|c|c|c|c|}
\hline Hypothesis & $\begin{array}{l}\text { Direct without } \\
\text { Mediator }\end{array}$ & $\begin{array}{l}\text { Direct with } \\
\text { Mediator }\end{array}$ & Indirect effect & $P$ & $S E$ \\
\hline $\mathrm{MGM} \rightarrow \mathrm{SCPD}$ & -0.096 & -- & -- & 0.000 & 0.006 \\
\hline $\mathrm{MGM} \rightarrow$ CPDT & 0.120 & -- & -- & 0.000 & 0.008 \\
\hline $\mathrm{SC} \rightarrow \mathrm{SCPD}$ & -0.082 & -- & -- & 0.000 & 0.005 \\
\hline $\mathrm{SC} \rightarrow \mathrm{CPDT}$ & -0.385 & -- & -- & 0.000 & 0.008 \\
\hline$U \rightarrow S C P D$ & 0.090 & -- & -- & 0.000 & 0.006 \\
\hline $\mathrm{H} \rightarrow \mathrm{SCPD}$ & 0.228 & -- & -- & 0.000 & 0.007 \\
\hline $\mathrm{EN} \rightarrow \mathrm{SCPD}$ & 0.373 & -- & -- & 0.000 & 0.007 \\
\hline$\cup \rightarrow C P D T$ & 0.045 & -- & -- & 0.000 & 0.009 \\
\hline $\mathrm{H} \rightarrow \mathrm{CPDT}$ & 0.344 & -- & -- & 0.000 & 0.009 \\
\hline $\mathrm{SR} \rightarrow \mathrm{MGM} \rightarrow \mathrm{SCPD}$ & -- & 0.122 & 0.034 & 0.001 & 0.002 \\
\hline $\mathrm{R} \rightarrow \mathrm{SC} \rightarrow \mathrm{SCPD}$ & -- & -- & -0.015 & 0.001 & 0.001 \\
\hline $\mathrm{C} \rightarrow \mathrm{SC} \rightarrow \mathrm{SCPD}$ & -- & -- & -0.007 & 0.001 & 0.001 \\
\hline $\mathrm{R} \rightarrow \mathrm{SC} \rightarrow \mathrm{CPDT}$ & -- & -- & -0.071 & 0.001 & 0.003 \\
\hline $\mathrm{C} \rightarrow \mathrm{SC} \rightarrow \mathrm{CPDT}$ & -- & -- & -0.034 & 0.001 & 0.004 \\
\hline $\mathrm{R} \rightarrow \mathrm{MGM} \rightarrow \mathrm{SCPD}$ & -- & -- & -0.028 & 0.001 & 0.002 \\
\hline $\mathrm{C} \rightarrow \mathrm{MGM} \rightarrow \mathrm{SCPD}$ & -- & -- & -0.010 & 0.001 & 0.001 \\
\hline $\mathrm{R} \rightarrow \mathrm{MGM} \rightarrow \mathrm{CPDT}$ & -- & -- & 0.035 & 0.001 & 0.003 \\
\hline $\mathrm{C} \rightarrow \mathrm{MGM} \rightarrow \mathrm{CPDT}$ & -- & -- & 0.012 & 0.001 & 0.002 \\
\hline $\mathrm{SR} \rightarrow \mathrm{MGM} \rightarrow \mathrm{CPDT}$ & -- & -- & -0.043 & 0.001 & 0.003 \\
\hline
\end{tabular}

Note. Satisfaction with CPDT programs $=$ [SCPD], participation in CPDT programs = [CPDT], school management $=[\mathrm{MGM}]$, school climate $=[\mathrm{SC}]$, usefulness $=[\mathrm{U}]$, rewards $=[\mathrm{R}]$, help in everyday activities $=[\mathrm{H}]$, certificates $=[\mathrm{C}]$, educational needs $=[$ EN], self-realization $=[S R]$ 
When we included controls (employees' tenure and gender) as moderating variables we found that:

- employees' tenure strengthens the positive relationship between possibility for obtaining some reward and perception of school management as effective,

- employees' tenure dampens the negative relationship between self-realization and school climate,

- while gender strengthens the negative relationship between educational needs and school management.

Multigroup comparison showed that groups are not different at the model level; however, they may be different at the path level. Moreover, the structural model is not different between the groups of male and female teachers.

\section{Discussion}

Results of this study generally support proposal that interconnections of incentives, motives, organizational characteristics, participation in the continuing development activities, and satisfaction with these activities are very complex; they interfere each other in many ways. We found that participation in and satisfaction with CPDT programs are significantly affected by different motives and incentives (usefulness, rewards, help in everyday activities, certificates, educational needs, and self-realization), that perception of the school management as effective and school climate as supportive have positive effects on participation in CPDT programs, and that outcomes of effective school management and supportive school climate on participation in CPDT programs are influenced by different incentives and motives. Such findings could be supported by result given by Ryan and Deci that for optimal performance, extrinsic, intrinsic and autonomous motivations are necessary and that they are "often interactive rather than directly correlated or additive" (Ryan \& Deci, 2017, p. 545).

Most researchers found strong correlations between teacher's motivation to participate in CPDT programs with individual factors (Jones \& Lowe, 1985, Livneh \& Livneh, 1999, as cited in Smith et al., 2003). Based on presented data, we identified employees' tenure as an influential factor for perception of CPDT program. The length of employees' tenure strengthens the positive relationship between possibility for obtaining some reward and perception of school management as effective and dampens the negative relationship between self-realization and school climate (the longer employees' tenure is, they perceive the more positive relationship between possibility for obtaining some reward and perception of school management as more effective and less negative relationship between self-realization and school climate). An additional implication that can be drawn from identified moderating effects is that as longer is teachers' tenure, they will see more possibility for obtaining some reward, they will more often perceive school management as effective, and they will see more capacities for self-realization and they will more often recognize school climate as positive. Length of teachers' tenure thus is not the only important individual factor that influence perception of employees that drive them to participate in CPDT, but a factor directly related to strategic management. 
We also found that male teachers express less educational needs and only seldom they perceive school management as effective, which correspond to earlier findings (Mayr \& Müller, 2010; Radović, 2007; Ryan \& Deci, 2017) that gender (and sexual roles) are related to broad spectrum of incentives and motives connected to CPDT.

A few studies explored teacher's motivation to participate in CPDT programs from the perspective of the organizational factors, i.e. leadership (Bollough, et al, 1997, Sparks, 1995, as cited in Smith et al., 2003) and school climate (Grossman et al., 2000, as cited in Smith et al., 2003). The results of this study demonstrate significant correlations between perception of school management as effective and school climate as supportive with satisfaction with CPDT and participation in CPDT programs.

Interconnections of perception of school management and school climate with satisfaction with CPDT and participation in CPDT programs is very complex, too. Our findings demonstrated that perception of the school management both as effective and not effective have significant direct effects on SCPD and CPDT, and that perception of the school climate both as supportive and as not supportive have significant direct effects on SCPD and CPDT. Reported findings suggest that if teachers perceive school climate as supportive, their satisfaction with CPDT programs, and participation in CPDT will be higher, while if teachers perceive school climate as unsupportive, their satisfaction with CPDT programs, and participation in CPDT will be lower, that is congruent with findings of Ryan and Deci (Ryan \& Deci, 2017) about tendency of people to act defensive or compensatory in inadequate organizational context.

Furthermore, if teachers perceive school management as effective, their satisfaction with CPDT will be lower, although their participation in CPDT programs will be higher. The results extended these by revealing that if teachers perceive CPDT programs as useful for their performance, if they perceive that these programs could help them in everyday activities, and that these programs could satisfy their educational needs, their satisfaction with participation in CPDT programs will be higher. Also, if teachers perceive CPDT programs as possibility for self-realization, and their school management as effective, they will be more satisfied with CPDT programs.

Obtained results could explain some aspects of complex interplay of rewards and certificates with perceived school management and school climate: if teachers do not see possibility to obtain some reward or certificate, but they perceive school climate as supportive, then they will be more satisfied with CPDT programs, and they would more participate in them, that indicate importance of coherence between supportive school climate and CPDT. Also, if teachers perceive school management as effective, but do not see possibility to obtain some reward or certificate, they will be more satisfied with CPDT programs, although, if they see possibility to obtain some reward or certificate, they will more participate in CPDT programs, that indicate importance of effective school management on satisfaction and participation in CPDT programs. Subsequently, if teachers perceive school management as effective, they will not perceive simple participation in CPDT programs as possibility for self -realization - effective school management will develop such organizational climate that promote school into the learning organization (Ovesni, 2014). 


\section{Conclusion}

The current research revealed that careful consideration should be given to the motivation and incentives that drives teachers to participate in CPDT programs and to be satisfied with them. From andragogical standpoint, special attention should be given to planning and development of CPDT programs that are useful for teachers' performance, that could help them in everyday activities, that opens possibilities for self-realization, i.e. to CPDT programs that are developed in accordance to fundamental andragogical principles, and based on diagnosed needs for learning (Knowles, Holton, \& Swanson, 2015; Krnjaja, 2013; Ovesni, Radović, \& Alibabić, 2014). Viewed from pedagogical and concepts of noncoercive and effective educational management, organizational climate and learning organization, and self-determination theory (SDT) standpoints, special attention should be given to development of effective school management and school climate conductive for learning. For school setting, findings imply emphasis on organizational climate related to CPDT for the reasons discussed by Knowles and associates that if the [school] climate „is not really conducive to learning, if it doesn't convey that organization values human beings as its most valuable asset and their development its most productive investment, then all the other elements in the process are jeopardized" (Knowles et al, 2015, p. 59).

However, some limitations should be noted. Although the sample size was sufficient for our statistical analysis, it was too large by reason that the $x 2$ test is dependent on sample size and could reject reasonable models if sample size is too large (Hoyle, 2012). Besides, even respondents were assured in anonymity, social desirability could be present in the data, while positive/negative affectivity could cause response bias, too. Also, because study is based on self-reported data, and administrated by undergraduate research trainees there is the possibility of common method variance. To overcome this potential issue a follow up test should be performed at similar, but smaller target sample in terms of longitudinal approach. Since data were collected in Serbia, which could be considered as a purposive sampling approach, possibility for broader generalization were limited, too.

Still, to enhance generalizability of data and to obtain more accurate results some further researches are necessary, although this study broadens the locus of researchers from influences of participation in CPDT on teaching practice to motivation of teachers to participate in CPDT programs, to different influences of individual characteristics of employees (age, gender, employees' tenure) and organizational characteristics on teacher's development. Apparently, this study presents a start for future, deeper theoretical insights and empirical researches, while regarding practical implications, our findings draws a framework for designing purposeful CPDT programs considering different motives and incentives that drives teachers to participate in CPDT, in the light of concepts of effective school management and supportive school climate. 


\section{Literature}

Adelman, H. S., \& Taylor, L. (2005). Classroom climate. In S. W. Lee, P. A. Lowe, \& E Robinson (Eds.), Encyclopedia of school psychology (pp. 88-90). Thousand Oaks, CA: Sage.

Bennett, N. (2003). Structure, culture and power in organisations. In N. Bennett, M. Crawford, \& M. Cartwright (Eds.), Effective educational leadership (pp. 44-61). London, GB:The Open University \& Paul Chapman Publishing, A SAGE Publications Company.

Caldwell, B. J. (2003). A theory of learning in the self-managing school. In A. Volansky, \& I. A. Friedman (Eds.), School-based management: An international perspective (pp. 57-93). Jerusalem, IL: Ministry of Education of Israel.

Carr, J. F., Hermann, N., \& Harris, D. E. (2005). Creating dynamic schools through mentoring, coaching and collaboration. Alexandria, VA: Association for Supervision and Curriculum Development.

Carr, W., \& Kemmis, S. (2000). Becoming critical (education, knowledge and action research). London, GB: The Falmer Press.

Clement, M., \& Vanderberghe, R. (2001). How schools leaders can promote teachers' professional development: An account from the field. School Leadership and Management, 21(1), 43-57, https:// doi.org/10.1080/13632430120033036

Cohen, J. (2006). Social, emotional, ethical, and academic education: Creating a climate for learning, participation in democracy, and well-being. Harvard Educational Review, 76(2), 201-237, https:// doi.org/10.17763/haer.76.2.j44854x1524644vn

European Commission(2007). Key competences for lifelong learning - A European framework. Luxembourg, LU: Office for Official Publications of the European Communities.

European Commission (2010). Common European principles for teacher competences and qualifications. Brussels, BE: Eurydice.

Gamage, D. T. (2009). Managing school change: Continuous improvement based on a shared vision and a strategic plan. In J. Zajda\& D. Gammage (Eds.), Decentralisation, school-based managementand quality (pp. 103-123). London, GB: Springer.

Gruenert, S., \& Whitaker, T. (2015). School culture rewired: how to define, assess, and transform it. Alexandria, VA: ASCD.

Harris, A., \& Chrispeels, J. H. (Eds.) (2006). Improving schools and educational systems. London, GB, and New York, NY: Routledge.

Hausman, C., \& Murphy, J. (2015). Fundamental shifts in schooling: Implications for principal leadership. In B. Moon, M. Ben Peretz, \& S. Brown (Eds.), Routledge international companion to education (pp. 283-291). London, GB, and New York, NY: Routledge.

Hebib, E. (2013). Kako razvijati školu: razvojni i reformski procesi u oblasti školskog obrazovanja. Beograd: Institut za pedagogiju i andragogiju, Filozofski fakultet Univerziteta u Beogradu.

Hebib, E., \& Žunić Pavlović, V. (2018). Školska klima i školska kultura: okvir za izgradnjuškole kao bezbedne i podsticajne sredine za učenje i razvoj. Zbornik Instituta za pedagoška istrazivanja, 50(1), 113-134. https://doi.org/10.2298/ZIPI1801113H

Hoyle, R. H. (Ed.) (2012). Handbook of Structural Equation Modeling. New York, NY: The Guilford Press.

Khine, M. S. (Ed.) (2013). Application of structural equation modeling in educational research and practice. Rotterdam, NL: Sense Publishers. 
Knowles, M. S., Holton, III E. F., \& Swanson, R. A. (2015). The adult learner: The definitive classic in adult education and human resource development, VIII ed. Abingdon, GB: Routledge.

Krnjaja, Ž. (2013). Opportunities for lifelong learning through the professional development of teachers in Serbia. In N. A. Lobanov, V. N. Skvortsov (Eds.), Lifelong learning: continuous education for sustainable development: proceedings of 11th International Cooperation(pp. 93-95). SaintPetersburg, RU: Pushkin Leningrad State University.

Mayr, J., \& Müller, F. H. (2010). Wovon hängt es ab, wie und wieviel sich Lehrerinnen und Lehrer fortbilden? In J. Schmich, \& C. Schreiner (Hrsg.), BIFIE-Report 4/2010, TALIS 2008: Schule als Lernumfeld und Arbeitsplatz. Vertiefende Analysen aus österreichischer Perspektive (pp. 11-25). Salzburg, AT: Zentrum für Bildungsmonitoring \& Bildungsstandards.

Minton, M. K. (2013). Motivation. In V.Smith (Ed.), Sociology of work: An encyclopedia (pp. 612-614). Thousand Oaks, CA: Sage Publications.

Mooney, N. J., \& Mausbach, A. T. (2008). Align the desing: A blueprint for school improvement. Alexandria, VA: Association for Supervisionand Curriculum Development.

Moos, L., \& Huber, S. (2007). School leadership, school effectiveness and school improvement: Democratic and integrative leadership. In T.Townsend (Ed.), International handbook of school effectiveness and improvement (pp. 579-595). Dordrecht, NL: Springer.

Osborne, S. P., \& Brown, K. (2005). Managing Change and Innovation in Public Service Organizations. London, GB: Routledge.

Ovesni, K. (2014). Organizacija koja uči: andragoška perspektiva. Beograd: Institut za pedagogiju i andragogiju, Filozofski fakultet Univerziteta u Beogradu.

Ovesni, K., Hebib, E., \& Radović, V. (2016). Implication of effective school management for the continuing professional development of teachers. In S. Petrovska (Ed.), Education in XXI century - conditions and perspectives - international scientific conference,book of proceedings (pp. 148-156). Shtip, MK: Faculty of Educational Sciences University "Goce Delcev".

Ovesni, K., Radović, V. \& Alibabić, Š. (2014). Posvećenost nastavnika profesiji i školi u kojoj su zaposleni. Nastava i vaspitanje, 63(4), 465-480.

Pravilnik o stalnom stručnom usavršavanju i sticanju zvanja nastavnika, vaspitača i stručnih saradnika (2015). Službeni glasnik Republike Srbije, br. 86/2015.

Radović, V. (2007). Feminizacija učiteljskog poziva. Beograd: Učiteljski fakultet Univerziteta u Beogradu.

Radulović, L. (2016). Slike o nastavniku: između moderne i postmoderne.Beograd: Institut za pedagogiju i andragogiju, Filozofski fakultet Univerziteta u Beogradu.

Ryan, R. M., \& Deci, E. L. (2017). Self-determination theory -- Basic psychological needs in motivation, development, and wellness. New York, NY: The Guilford Press.

Sinclair, C., Dowson, M., \& McInerney, D.M. (2006). Motivations to teach: Psychometric perspectives across the first semester of teacher education. Teachers College Record, 108, 1132-1154.

Smith, C., Hofer, J., Gillespie, M., Solomon, M., \& Rowe, K. (2003). How teachers change: A study of professional development in adult education (NCSALL Rep. No. 25). Boston, MA: National Center for the Study of Adult Learning and Literacy.

Stančić, M. (2015). Nastavničke refleksije o evaluaciji sopstvenog rada. Nastava i vaspitanje, 65(4), 697-713. https://doi.org/10.5937/nasvas1504697S 
Stoll, L., Bolam, R., McMahon, A., Wallace, M., \& Thomas, S. (2006). Professional learning communities: A review of the literature. Journal of Educational Change, 7(4), 221-258, https://doi.org/10.1007/ s10833-006-0001-8

Šefer, J. (2015). Motivisanost nastavnika osnovne škole za promene u nastavi. Nastava i vaspitanje, 64(4), 285-299. https://doi.org/10.5937/nasvas1502285S

Thapa, A., Cohen, J., Guffey, S., \& Higgins-D’Alessandro, A. (2013). A review of school climate research. Review of Educational Research, 83(3), 357-385, https://doi.org/10.3102/0034654313483907

Zakon o osnovama sistema obrazovanja i vaspitanja (2013). Službeni glasnik Republike Srbije, br. 55/2013.

Примљено: 11.08.2019.

Прихваћено за штампу: 13.09.2019.

\title{
Континуирани професионални развој наставника: међусобна игра школског менаџмента, школске климе, мотивације и инсентива
}

\author{
Кристинка Овесни \\ Катедра за педагогију и андрагогију, Филозофски факултет, \\ Универзитет у Београду, Србија \\ Емина Хебиб \\ Катедра за педагогију и андрагогију, Филозофски факултет, \\ Универзитет у Београду, Србија \\ Вера Радовић \\ Учитељски факултет, Универзитет у Београду, Србија
}

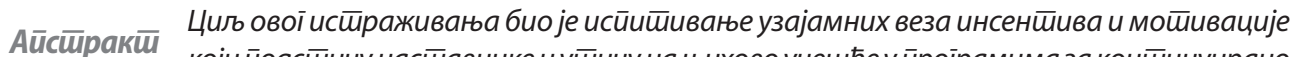

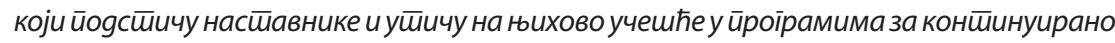

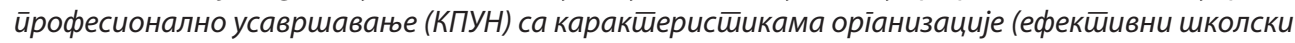

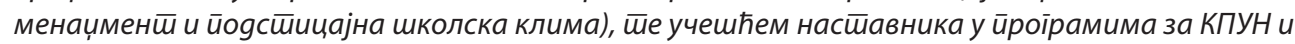

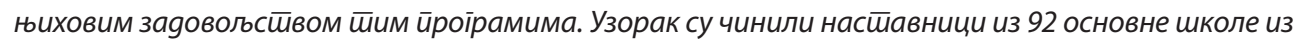

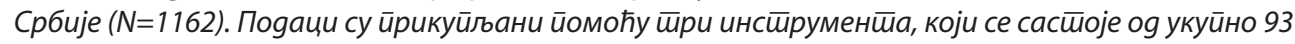

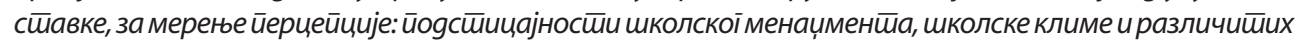

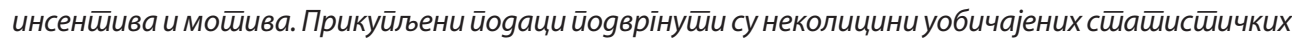

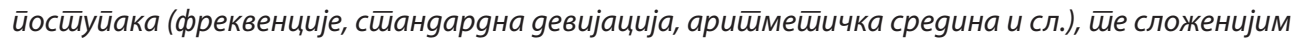

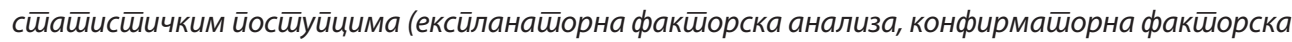

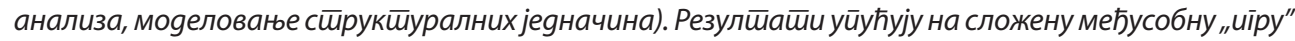

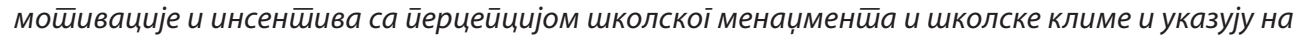
ӣоширебуза gейаљьим йланирањем, развојем и реализацијом йроірама за КПуН који би били корисни за свакояневи йосао насииавника, њихову самореализацију и йобољшане йерформансе, gок би у

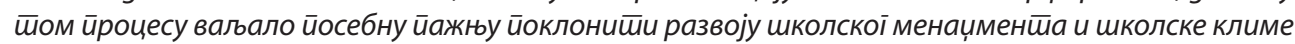

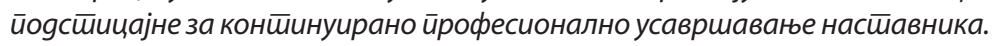

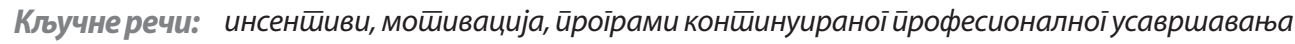
насйавника, школска клима, школски менаименй. 


\title{
Непрерывное профессиональное развитие преподавателей: совместная игра школьного менеджмента, школьного климата, мотивации и побуждения
}

\author{
Кристинка Овесни \\ Кафедра педагогики и андрагогики, Философский факультет, \\ Университет в Белграде \\ Эмина Хебиб \\ Кафедра педагогики и андрагогики, Философский факультет, \\ Университет в Белграде \\ Вера Радович \\ Факультет для подготовки учителей начальной школы, \\ Университет в Белграде
}

\begin{abstract}
Резюме Целью данного исследования было изучение взаимной связи побуждения и мотивации, которые стимулируют преподавателей и влияют на их участие в программах непрерывного профессионального развития (ПНПР) схарактеристиками организации (эффективное управление школой и благоприятный школьный климат), а также с вовлечением учителей в программы ПНПР и их удовлетворенность этими программами. В исследовании приняли участие преподаватели из 92 восьмилетних школ в Сербии ( $N=1162)$. Данные собраны с использованием трех инструментов, состоящих из 93 пунктов, для измерения восприятия, а именно: активность школьного менеджмента, школьный климат и различные побуждения и мотивы. Собранные данные подвергнуты нескольким общим статистическим прочедурам (частота, стандартное отклонение, арифметическая среда и т. n.) и более сложным статистическим процедурам (объяснительный факторный анализ, подтверждающий факторный анализ, моделирование структурных уравнений). Результаты указывают на сложную взаимную "игру" мотивации и побуждений с восприятием школьного менеджмента и школьным климатом, а также на необходимость детального планирования, разработки и реализации программ НПР, которые были бы полезны в повседневной работе преподавателей, их самореализации и повышении компетентности. Одновременно, особое внимание следует уделять развитию школьного менеджмента и школьного климата, что способствовало бы постоянному профессиональному развитию преподавателей и учителей.
\end{abstract}

Ключевые слова: побуждения, мотивачия, программы непрерывного профессионального развития учителей, школьный климат, школьный менеджмент. 